\title{
Pengaruh Pembelajaran Berbasis Multiliterasi Terhadap Kemampuan Berpikir Kritis
}

\section{Cholifah Tur Rosidah}

\author{
Pendidikan Guru Sekolah Dasar \\ Fakultas Keguruan dan Ilmu Pendidikan \\ Universitas PGRI Adi Buana Surabaya \\ cholifah@unipasby.ac.id
}

\begin{abstract}
Abstrak
Penelitian ini bertujuan untuk mengetahui adakah pengaruh pembelajaran berbasis multiliterasi terhadap kemampuan berpikir kritis mahasiswa. Penelitian dilakukan dengan latar belakang rendahnya kemampuan berpikir kritis mahasiswa. Desain penelitian yang digunakan ialah kuantitatif dengan bentuk Quasi Eksperimental Design bentuk Non-Equivalent Control Group Design. Populasi dalam penelitian ini ialah seluruh mahasiswa PGSD yang memprogram mata kuliah pembelajaran Bahasa Indonesia yang terbagi dalam kelas 2016 A, B, C, D, dan E. Namun, sampel yang terpilih sesuai tujuan penelitian ialah kelas B sebagai kelas eksperimen dan kelas $\mathrm{C}$ sebagai kelas kontrol. Teknik pengumpulan data dilakukan melalui pretest dan posttest yang berisi tentang materi pembelajaran bahasa Indonesia di SD. Tes yang diberikan sebelumnya telah melalui uji validitas dengan skor 1, uji realibilitas dengan skor 0,685.Skor tersebut menunjukkan bahwa instrumentes telah valid, dan reliabel. Selanjutnya data yang telah didapat dianalisis dengan menggunakan teknik Test-t dengan skor0,036 yang sebelumnya telah didahului dengan melakukan uji normalitas yang menunjukkan bahwa data telah normal. Selanjutnya dilakukan uji hipotesis yang mendapatkan hasil H0 ditolakberarti bahwa terdapat pengaruh pembelajaran berbasis multiliterasi terhadap kemampuan berpikir kritis mahasiswa.
\end{abstract}

Kata kunci: Pembelajaran, Multiliterasi, Berpikir Kritis.

\section{PENDAHULUAN}

Keberhasilan pembelajaran yang diraih oleh peserta didik ditentukan oleh proses pembelajaran yang dilaluinya. Dalam proses tersebut model pembelajaran yang digunakan mempunyai peran besar dalam penentuan alur pembelajaran. Model pembelajaran merupakan sistematika pembelajaran yang menggambarkan proses dalam pengorganisasian pengalaman belajar peserta didik. Model pembelajaran yang sesuai dengan karakteristik materi dan karakteristik peserta didik memungkinkan dapat terlaksanapembelajaran yang lebih efektif dan efisien, sehingga dapat memberikan hasil yang optimal,begitupun sebaliknya.
Pembelajaran bahasa Indonesia memiliki peran penting dalam pembinaan keterampilan berkomunikasi, juga dalam penguasaan ilmu pengetahuan. Ghazali (2013), menjelaskan pembelajaran bahasa Indonesia merupakan proses yang berjalan linier yang berarti diawali dengan pengusaan bahasa lisan, kemudian dilanjutkan dengan penguasaan bahasa tulis. Setelah menguasai keterampilan-keterampilan tersebut, maka akan mudah untuk menubuhkembangkan keterampilan lainnya.

Literasi bukan hanya sekedar keberaksaraan yang terlihat dari kegiatan membaca dan menulis. Namun lebih dari itu, mencakup keterampilan berpikir menggunakan sumber-sumber pengetahuan 
dalam bentuk cetak, visual, digital, dan audiotori. Literasi juga berkaitan dengan pemikiran manusia. Seseorang yang memiliki tingkat literasi tinggi, mampu membaca dengan baik berbagai aspek kehidupan, termasuk membaca tanda-tanda zaman. Seseorang tidak akan mampu menjadi filsuf, andaikata kemampuan literasinya tidak baik (Dharma dalam Sudikan: 2017). Literasi memiliki posisi strategis dalam dunia pendidikan. Membacaberpikir-menulis yang merupakan inti literasi sangat diperlukan mahasiswa sebagai intelektual muda. Baik dalam melaksanakan studi, maupun mempersiapkan diri memasuki dunia pekerjaan, dan belajar sepanjang hayat di tengah masyarakat. Oleh karena itu, sangat beralasan apabila literasi dijadikan basis pengembangan kegiatan pembelajaran dalam proses perkuliahan, berarti aktivitas yang dirancang dalam proses perkuliahan bertumpu pada kegiatan membaca-berpikir-menulis dan kegiatan lain yang menyertainya seperti berdiskusi, memecahkan masalah, menyusun makalah, meneliti dan melaporkan (Suyono: 2009).

Beberapa macam literasi diantaranya literasi komputer (computer literacy), literasi media (media literacy), literasi teknologi (technology literacy), literasi ekonomi (economy literacy), literasi informasi (information literacy), dan literasi moral (moral literacy). Sehingga literasi dapat diartikan melek teknologi, melek informasi, berpikir kritis, dan peka terhadap lingkungan. Seseorang dikatakan literat apabila ia dapat memahami sesuatu karena membaca informasi yang tepat dan melakukan sesuatu berdasarkan pemahamannya terhadap isi bacaan tersebut (Sakti: 2012).

Multiliterasi menjadi paradigma baru dalam pembelajaran. Konsep multiliterasi hadir karena literasi tidak hanya sekedar membaca dan menulis, namun banyak hal terkait dengan konsep literasi yang harus dikuasai. Keterampilan yang harus dikuasai agar terwujud pembelajaran berbasis multiliterasi antara lain kemampuan pemahaman bacaan, kemampuan menulis, kemampuan berbicara, dan kemampuan penguasaan berbagai media digital (Marocco: 2008). Melalui pembelajaran berbasis multiliterasi, peserta didik dapat mengoptimalkan keterampilan berbahasa hingga dapat menumbuhkembangkan keterampilan berpikir kritis, pemahaman konseptual, kolaboratif, dan komunikatif. Adapun sintaks pembelajaran berbasis multiliterasi antara lain, 1) memahami, 2) memaknai, 3) menafsirkan, merekonstruksi, 5) medekonstruksi, 6) melaporkan, dan 7) mempresentasikan (Sudikan: 2017).

Berpikir kritis merupakan proses berpikir secara tepat, terarah, beralasan, dan reflektif dalam pengambilan keputusan yang dapat dipercaya. Peserta didik yang mempunyai keterampilan berpikir kritis dapat dilihat dari indikator yang ditunjukkannya seperti, 1) mampu menilai pertanyaan dan argumen, 2) mampu memperbaiki miskonsepsi mapun informasi, 3) memiliki rasa ingin tahu yang tinggi, 4) tertantang untuk menemukan solusi baru dari setiap permasalahan, 5) mampu menangkap informasi dan memberikan feedback, 6) mencari bukti ilmiah untuk mendukung asumsi dan keyakinan, 7) dapat menolak informasi bila tidak benar atau tidak relevan.

Namun berdasarkan hasil observasi awal tentang kemampuan berpikir mahasiswa saat proses perkuliahan di dalam kelas, peneliti memperoleh data bahwa terdapat perbedaan cara berpikir yang diperlihatkan oleh masing-masing kelas yang menempuh mata kuliah pembelajaran Bahasa Indonesia. Dari 5 kelas yang memprogram mata kuliah Pembelajaran 
Bahasa Indonesia, ada 2 kelas yang terlihat kurang dibandingkan dengan 3 kelas lainnya. Tiga kelas diantaranya menunjukkan $80 \%$ mahasiswa di dalamnya rata-rata mampu memahami dan mengkritisi setiap permahasalahan yang dihadirkan di dalam kelas dengan sangat baik. Hal tersebut ditunjukkan dengan selalu mengikuti setiap proses pembelajaran di kelas dengan antusiasme dan motivasi yang tinggi. Selain itu diskusi pun dapat berjalan lancar, mampu menganalisis informasi yang diperoleh dan mengungkapkan kembali sesuai pemahamannya, selalu sigap dan tegas dalam menjawab pertanyaan maupun permasalahan yang muncul, serta mampu menyelesaikan tugas dengan benar dan tepat waktu. Namun, 2 kelas lainnya menunjukkan perbedaan yang signifikan. Seperti berbanding terbalik, dalam kelas tersebut hanya 30\% mahasiswa yang menunjukkan memiliki keterampilan berpikir baik, sisanya hanya mengikut proses perkuliahan dengan datang, duduk, dan diam. Hal itulah yang menjadi dasar penelitian pengaruh pembelajaran multiliterasi terhadap kemampuan berpikir kritis mahasiswa.

Penelitian ini bertujuan untuk mengetahui adakah pengaruh pembelajaran berbasis multiliterasi terhadap kemampuan berpikir kritis mahasiswa.

\section{METODE PENELITIAN}

Penelitian ini merupakan penelitian kuantitatif dengan desain Quasi Experimental Designyang bertujuan untuk mengetahui adakah pengaruh model pembelajaran berbasis multiliterasi terhadap kemampuan berpikir kritis mahasiswa. Dalam penelitian ini terdapat satu kelas eksperimen dan satu kelas kontrol. Kelas eksperimen merupakan kelompok mahasiswa yang diberi treatment dengan pelaksanaan pembelajaran berbasis multiliterasi, sedangkan kelas kontrol sebagai pemanding merupakan kelompok mahasiswa yang tidak diberi treatment, dalam arti pelaksanaan pembelajaran dilaksanakan dengan menggunakan model Contextual Teaching and Learning. Dalam penelitian ini pembelajaran berbasis multiliterasi menjadi variabel bebas dan kemampuan berpikir kritis menjadi variabel terikat.

Quasi eksperimental design banyak digunakan dalam penelitian pendidikan yang subjek peneitiannya tidak dapat dimanipulasi dan dikontrol secara intensif (Syamsudin: 2011). Selanjutnya penelitian ini menggunakan desain Quasi eksperimen non-equivalent groups pretest-posttest. Adapun desainnya dapat dilihat pada tabel 1.

Tabel 1. Desain Penelitian

\begin{tabular}{|c|c|c|c|}
\hline Sampel & Pretest & Treatment & Posttest \\
\hline $\mathrm{R}_{1}$ & $\mathrm{O}_{1}$ & $\mathrm{X}$ & $\mathrm{O}_{3}$ \\
\hline $\mathrm{R}_{2}$ & $\mathrm{O}_{2}$ & - & $\mathrm{O}_{4}$ \\
\hline
\end{tabular}

Keterangan:

$\mathrm{R}_{1} \quad$ : Kelas Eksperimen

$\mathrm{R}_{2} \quad$ : Kelas Kontrol

$\mathrm{O}_{1} \quad$ : Hasil Pretest Kelas Eksperimen

$\mathrm{O}_{2} \quad$ : Hasil Pretest Kelas Kontrol

$\mathrm{X}$ : Perlakuan dengan menerapkan pembelajaran berbasis multiliterasi

$\mathrm{O}_{3} \quad$ : Hasil Posttest Kelas Eksperimen

$\mathrm{O}_{4} \quad$ : Hasil Posttest Kelas Kontrol

Berdasarkan tabel tersebut prosedur yang harus dilakukan dalam penelitian antara lain persiapan, pelaksanaan atau pengumpulan data penelitian, analisis data hasil penelitian dan penyusunan laporan.Penelitian dilakukan di program studi pendidikan guru sekolah dasar Universitas PGRI Adi Buana Surabaya pada waktu perkuliahan semester genap 2017/2018.

Adapun populasi dalam penelitian ini ialah seluruh mahasiswa PGSD yang 
memprogram mata kuliah pembelajaran Bahasa Indonesia sejumlah 181 mahasiswa. Mahasiswa tersebut terbagi dalam 5 kelas, antara lain 36 mahasiswa di kelas A, 36 mahasiswa di kelas $\mathrm{B}, 38$ mahasiswa di kelas C, 37 mahasiswa di kelas D, dan 34mahasiswa di kelas E.Selanjutnya penentuan sampel untuk kelas eksperimen dan kelas kontrol dilakukan dengan menggunakan teknik purposive sampling dengan tujuan memperoleh sampelyang sesuai dengan tujuan penelitian. Sehingga, sampel yang di dapat ialah mahasiswa yang memprogram mata kuliah pembelajaran Bahasa Indonesia di kelas Bdan kelas C.

Sampel yang berada di dalam kelas Csebagai kelas kontrol terdiri dari 3 mahasiswa berjenis kelamin laki-laki dan 33 perempuan. $3 \%$ dari mereka berusia lebih dari 24 tahun, dan $97 \%$ lebihnya berusia antara 19-22 tahun. 13\% diantaranya membaca buku antara 30 sampai 60 menit dalam sehari dan sisanya sebanyak $87 \%$ membaca buku kurang dari 30 menit dalam sehari. Selanjutnya sampel yang berada di kelas B sebagai kelas eksperimen terdiri dari 5 mahasiswa berjenis kelamin laki-laki dan 31 perempuan. Semua berusia antara 19-22 tahun. Kegiatan literasi berupa membaca buku yang mereka lakukan tidak jauh berbeda dengan sampel yang berada pada kelas kontrol. Hanya 19\% dari mereka yang membaca buku dalam kurun waktu 30-60 menit sehari. Selebihnya $81 \%$ hanya membaca buku dalam kurun waktu kurang dari 30 menit dalam sehari.

Instrumen yang digunakan dalam penelitian ini berupa tes. Instrument berupa tes diberikan saat pretest dan posttest. Sebelum instrument tersebut digunakan, terlebih dahulu dilakukan uji instrument dengan uji validitas dan uji realibilitas.

Data yang telah terkumpuldari hasil tes selanjutnya dianalisis dengan menggunakan uji-t yang sebelumnya di dahului dengan uji normalitas. Setelah dilakukan uji normalitas pada sampel, selanjutnya dilakukan uji hipotesis.

\section{HASIL DAN PEMBAHASAN}

Berdasarkan metode penelitian yang telah dipaparkan hasil yang di dapat untuk uji validitas tes tampak pada tabel 2 berikut.

Tabel 2. Validitas Tes

\begin{tabular}{|c|c|c|c|c|c|c|c|c|c|c|c|c|}
\hline & & twal & $x=2$ & Alus & $\operatorname{sen} t$ & $\operatorname{sen} 5$ & ins: & an? & . ists & 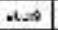 & xtailin & axcer-ora- \\
\hline \multirow[t]{3}{*}{$-a x$} & 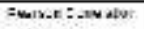 & & -265 & 1<27 & 5 & 305 & 102 & $\cos$ & at & 211 & 295 & 200 \\
\hline & 항 (8xasen) & & $: s:$ & $\ldots$ & ass & $n n$ & $\therefore=$ & rod & $x:=$ & . 21 & $\therefore x$ & we \\
\hline & is & $\therefore$ & 파 & $x$ & $x_{i}$ & vi & :A & A & $y$ & $x$ & $\mathrm{si}$ & * \\
\hline \multirow[t]{3}{*}{-1102} & 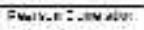 &.$\infty y_{1}$ & & sat & 230 & .250 & . ले & .2ख्य & .129 & -219 & कर & 国 \\
\hline & -6 (2 (2x)2) & 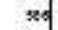 & & $\therefore:=$ & \% & $2 \pi$ & at & 128 & | & .21 & $s: s$ & es: \\
\hline & N & 36 & 18 & 28 & $s$ & $\%$ & 28 & 38 & $2:$ & $3:$ & 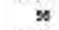 & 30 \\
\hline \multirow[t]{3}{*}{$=020$} & | ceres jace ant & $\therefore \Leftrightarrow$ & $\therefore+\infty$ & 1 & 200 & $\$ 21^{\circ}$ & $a=$ & $\omega_{0}$ & $\ldots$ & $.2=$ & $w_{24}$ & s:36 \\
\hline & she Gevan & at & -4 & & 319 & na: & $n$ & का & $=-12$ & $48-1$ & $7 \mathrm{st}$ & mil \\
\hline & $\mathrm{x}$ & $\Rightarrow$ & $i=$ & $\Delta=$ & s & s & $\Leftrightarrow$ & of & $\Delta=$ & $\Delta=$ & s & 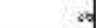 \\
\hline \multirow[t]{3}{*}{$-2 x=$} & 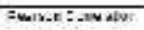 & Iश्न & .2120 & $21=$ & & .014 & लब & ल्कर्ष & ses & , 129 & 290 & $\$$ \\
\hline & - 0 a $12 x=29$ & 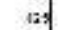 & $\mathrm{ma}$ & $A=$ & & 996 & 613 & wo & | & $1 \%$ & 1 & $\infty r$ \\
\hline & v & 8 & $=$ & $\Rightarrow$ & $\mathbf{x}$ & v & if & a & $y$ & $y$ & v & as \\
\hline \multirow[t]{3}{*}{$=020$} & certen janc anor & wat & 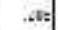 & 40 & jon & - & 201 & 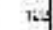 & . & $\mathrm{w}$ & 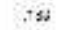 & $5 \times 2$ \\
\hline & $\because h(\theta+a k)$ & we. & $\Delta$ & $\therefore A_{2}$ & עs & & |י11 & +is & $.1 \% 4$ & $\therefore 4 \approx$ & $+\infty$ & w. \\
\hline & N & of & $s=$ & $d=$ & क & \% & in & $\therefore 0$ & dat & is & $\%$ & os \\
\hline \multirow[t]{3}{*}{ किकर्माi } & $\operatorname{sen} x x^{-1} \operatorname{sen} \operatorname{stan}$ & 1हि & -34 & त्य & nพ & $3 m$ & & क्रत्र & जे & क्य & $0 \%$ & कस \\
\hline & 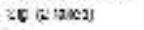 & $20:$ & קבו: & 138 & sis & 11 & & $2:$ & 1 & , & . 5 & $\infty 1$ \\
\hline & a & 20 & $3:$ & 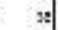 & 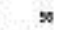 & $n$ & 30 & 20. & $s$ & $s:$ & $\infty$ & 30 \\
\hline \multirow[t]{3}{*}{$=c 2}$, & 1 certe jace ant & ver & $\therefore=$ & $. x=$ & USi & 22 & and & 1 & = & . & $\rightarrow \infty$ & 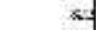 \\
\hline & Ste Guswa & $\mathrm{rat}$ & \pm & $=-1$ & ח & $\rightarrow$ & sct & & 20 & $x$ & smi & $r:$ \\
\hline & N & of & $i=$ & $d=$ & क & 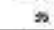 & of & $\cos$ & $d=$ & $\therefore$ & s & $\infty$ \\
\hline \multirow[t]{3}{*}{ 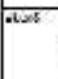 } & 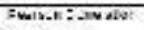 & 220 & .129 & an & 0,00 & $2 !$ & बत्ब & in & 1 & तन & 35 & 35 \\
\hline & $-5(2.2 x)$ & 158 & .18 & atd & $\pi z$ &,$\pi$ & 3 & $+15:$ & & a & $0=2$ & $\infty$ \\
\hline & n & $\theta$ & $y$ & $y$ & vi & ni & $\Rightarrow$ & - th & $y$ & $y$ & $\mathrm{n}$ & m \\
\hline \multirow[t]{3}{*}{$=050$} & I earten jaces 250 r & = & . & $a z=$ & $\therefore 2$ & 726 & ve: & wed & - & 1] & $\therefore 2$ & $.48:-$ \\
\hline & Ab pos & ats & ] & . & $\rightarrow$ S & 245 & 7 & $\mathrm{ses}$ & 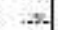 & & 48 & vis \\
\hline & $\mathrm{N}$ & $\Delta 6$ & $\Delta=$ & $\therefore=$ & s & $\%$ & $\cos$ & is & $\therefore=$ & $A$ & $\Rightarrow$ & 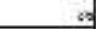 \\
\hline \multirow[t]{3}{*}{$\sin x$} & $\operatorname{sen} \pi x^{2}=\operatorname{sen} \sin$ & कर्व & -40 & $\pi$ & 5 & क्य & ल्य & ing & nan & 42 & 7 & $290^{\circ}-1-10$ \\
\hline & Sk, GutwI & ind & 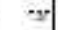 & 2 & +4. & $-4 n$ & -4. & and & " & $\mu=$ & & me \\
\hline & s & $\therefore$ & y & 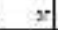 & $\mathrm{s}$ & si & As & : & $m$ & $y$ & $\mathrm{si}$ & 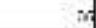 \\
\hline \multirow{3}{*}{ 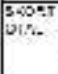 } & 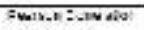 & $3 \infty$ & क्रा & 3256 & 138 & का & काश & 略 & 921 & का & 25 & \\
\hline & An paras & us & $\therefore s$ &. & wdi & טת & $\omega_{1}$ & tent & . n & 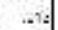 & NIZ & \\
\hline & $\approx$ & 30 & 표 & 28 & 30 & $\infty$ & 30 & 6 & D. & $3:$ & $s$ & 30 \\
\hline
\end{tabular}

Hasil perhitungan reliabilitas soal dengan menggunakan rumus Alfa Cronbach dapat dilihat pada tabel 3 berikut.

Tabel 3. Reliability Statistics

\begin{tabular}{|c|c|}
\hline $\begin{array}{c}\text { Cronbach's } \\
\text { Alpha }\end{array}$ & N of Items \\
\hline .685 & 11 \\
\hline
\end{tabular}

Hasil uji validitas 10 soal yang diujicobakan pada 36 mahasiswa yang tampak pada tabel 1 menunjukkan bahwa hasil $r_{x y}$ dibandingkan dengan $r$ tabel dengan taraf signifikansi 0,05 diketahui secara keseluruhan tes tersebut valid karena mendapat skor 1.Namun, dari skor total masing-masing soal, diketahui bahwa soal 
nomor 2 tidak valid karena hanya mendapat skor 0,081 kurang dari skor $r$ tabel.

Pada hasil penghitungan realibilitas didapat skor 0,685. Skor tersebut dibandingkan dengan skor $\mathrm{r}$ product moment menunjukkan bahwa soal yang diujicobakan bersifat reliabel.

Berdasarkan hasil uji validitas dan reliabilitas tes telah valid dan reliabel, shingga dapat diberikan pada kelas eksperimen dan kelas kontrol.

Berdasarkan uji normalitas data posttest kemampuan berpikir kritis kelas eksperimen dna kelas kontrol menyatakan bahwa data telah memenuhi syarat uji kenormalan. Kemudian dilanjutkan dengan uji t dengan taraf signifikansi 0,05 dengan hipotesis sebagai berikut:

1) $\mathrm{H}_{\mathrm{a}}: \mu_{1} \neq \mu_{2}$ artinya terdapat pengaruh pembelajaran berbasis multiliterasi terhadap kemampuan berpikir kritis berpikir kritis mahasiswa pada mata kuliah pembelajaran bahasa Indonesia di PGSD Unipa Surabaya. $\left(\mathrm{H}_{\mathrm{a}} \neq 0\right)$

2) $\mathrm{H}_{0}: \mu_{1}=\mu_{2}$ artinya tidak ada pengaruh pembelajaran berbasis multiliterasi terhadap kemampuan berpikir kritis berpikir kritis mahasiswa pada mata kuliah pembelajaran bahasa Indonesia di PGSD Unipa Surabaya. $\left(\mathrm{H}_{0}=0\right)$

Berdasarkan uji t yang dilakukan, diperoleh nilai Sig. (2 tailed) posttest kemampuan berpikir kritis mahasiswa sebesar 0,036 yang menunjukkan nilainya lebih kecil dari nilai $\alpha$. Maka kesimpulannya $\mathrm{H}_{0}$ ditolak, berarti terdapat pengaruh pembelajaran berbasis multiliterasi terhadap kemampuan berpikir kritis mahasiswa pada mata kuliah pembelajaran bahasa Indonesia di PGSD Unipa Surabaya.

Hasil uji hipotesis tersebut menunjukkan bahwa pembelajaran berbasis multiliterasi dapat berpengaruh terhadap kemampuan berpikir kritis mahasiswa. Tentunya juga harus didukung dengan partisipasi aktif mahasiswa selama proses pembelajaran berlangsung agar tujuan pembelajaran atau indikator kemmapuan berpikir kritis seperti memberikan penjelasan, membangunketerampilandasar, menyimpulkan, memberikan penjelasan lebih lanjut, dan mengatur strategi dan taktik dapat dicapai secara optimal.

Selain itu, dosen juga harus mampu mengoperasikan teknologi gara mampu membimbing dan mengarahkan mahasiswa untuk mengembangkan media kebutuhan pembelajaran secara luas. Berdasarkan penelitian yang telah dilakukan mahasiswa memperoleh informasi baru dari berbagai macam sumber belajar yang berkaitan dengan materi pembelajaran bahasa Indonesia di SD.

Masalah yang tak kalah penting dalam penelitian ini ialah dapat melaksanakan proses pembelajaran berbasis multiliterasi dengan baik, antara lain: (1) penyampaian tujuan pembelajaran, agar mahasiswa paham goal akhir yang harus mereka capai, (2) apersepsi sebagai pengait materi dan motivasi, (3) sintaks pembelajaran sesuai dengan tahapan pembelajaran berbasis multiliterasi, (4) sumber belajar yang beragam, (5) penilaian pembelajaran otentik, dan (6) memiliki luaran mampu mengembangkan kemampuan berpikir kritis dan kreatif mahasiswa, serta kemmpuan kolaborasi dan komunikasi yang baik dengan teman sejawat, guru, mupun masyarakat.

\section{SIMPULAN}

Berdasarkan data yang diperoleh, analisis, kajian teori, metode penelitian, serta pembahasan yang telah diuraikan sebelumnya, maka dapat disimpulkan bahwa terdapat pengaruh pembelajaran berbasis multiliterasi terhadap kemampuan berpikir kritis mahasiswa. 
Hasil temuan penelitian diharapkan dapat menjadikan sumbangsih inovasi pembelajaran dengan menerapkan pembelajaran berbasisi multilitersi agar anak Indonesia dapat berkembang menjadi pribadi-pribadi yang kritis, kreatif, dan inovatif.

\section{DAFTAR RUJUKAN}

Ghazali, S. 2013. Pembelajaran Keterampilan Berbahasa dengan Pendekatan Komunikatif Interaktif. Bandung: PT Refika Aditama.

Sudikan, S.Y. 2017. Pembelajaran Bahasa dan Apresiasi Sastra Berbasis Budaya. Sidoarjo: Satu Kata.

Suyono. 2009. Pembelajaran Efektif fan Produktif Berbasis Literasi: Analisis Konteks, Prinsip, dan wujud Alternatif Strategi Implementasinya di Sekolah. Jurnal Bahasa dan Seni, 37:203-217.

Sakti, T.P. 2012. Budaya Literasi Sebagai Relasi Dunia: Bentuk Kolonialisme Budaya, "Makalah Seminar Internasional Multikultural dan Globalisasi. UI 12-13 Desember 2012, 258-274.

Marocco,C.C. 2008. Supported Literacy For Adolescents: Transforming Teaching And Content Learning For The Twenty First Century. San Fransisco: Jossy-Bass A Wiley Imprint.

Syamsudin, A.R. \& Damayanti, V. 2011. Metode Penulisan Pendidikan Bahasa. Bandung: PT Remaja Rosdakarya.

Sukmadinata, N.S. 2013. Metode Penelitian Pendidikan. Bandung: PT Remaja Rosdakarya. 